\title{
Investigation of Liver Tissue and Biochemical Parameters of Adult Wistar Rats treated with Arctium lappa L.
}

\author{
Fabrícia Souza Predes*, Sérgio Luis Pinto da Matta, Juliana Castro Monteiro and Tânia \\ Toledo de Oliveira \\ Departamento de Biologia Geral; Universidade Federal de Viçosa; Av. P.H. Rolfs, s/n; Campus Universitário; \\ Viçosa - MG - Brasil
}

\begin{abstract}
This study was carried out to evaluate the effects of Arctium lappa L. (burdock) on the liver of adult male Wistar rats as measured by light microscopy and biochemical parameters. The rats received the extract in water bottles at doses of 10 or $20 \mathrm{~g} / \mathrm{L}$ daily for 40 days. There were no significant changes in the plasma levels of albumin, aspartate transaminase (AST), alanine transaminase (ALT), gamma glutamyl transferase (GGT), total protein, total cholesterol, urea, uric acid, triacylglycerol, calcium, phosphorus, chlorine and direct bilirubin. The morphological analysis did not reveal histopathological alterations in liver tissue. Both biochemical and morphological data did not indicate A. lappa toxicity.
\end{abstract}

Key words: Arctium lappa; Burdock; Plasma components; Liver

\section{INTRODUCTION}

Arctium lappa L. (burdock) is a plant brought from Japan and acclimated in Brazil, which is widely used in popular medicine all over the world (Pereira et al., 2005). This plant has long been cultivated as a vegetable for dietary use and is also used as a folk medicine, as a diuretic, antipyretic tea (Chen et al., 2004) as well as for hypertension, gout, hepatitis and other inflammatory disorders (Lin et al., 2002). Several studies have reported that the burdock possesses various pharmaceutical activities including an antibacterial activity (Pereira et al., 2005; Chen et al., 2004), antifungical activity (Pereira et al., 2005), antiplatelet-aggregating effect (Pereira et al., 2005; Lin et al., 2002), an antioxidant (Chen et al., 2004; Pereira et al., 2005; Leonard, et al., 2006), hepatoprotective efficacy (Lin et al., 2000; Lin et al., 2002) and anti-inflammatory activity (Lin et al., 1996; Chen et al., 2004). Pereira et al. (2005) have demonstrated that A. Lappa exhibits antimicrobial activity against oral microorganisms. In recent years, the crude water extract of A. lappa, called A. lappa tea, has become a promising and important beverage, because it has ample therapeutic action (Lin et al., 2002). It has been pointed out by various researchers that the extensive use of herbal medicines is not as safe, as is frequently claimed to be, and this medicinal plant may not be an exception. It can be harmful to take herbal medicines without being aware of their potential adverse effects (Capasso et al., 2000). In order to establish the therapeutic efficiency of these plants, scientific studies are essential. Since, the definition of hepatotoxicity is based on biochemical parameters (elevation of ALT, AST and GGT) or histological abnormality (Ozcanli,

\footnotetext{
*Author for correspondence: fpredes@yahoo.com.br
} 
2006), an investigation was carried out in controlled conditions to evaluate the possible effect of A. lappa on the liver and on biochemical parameters.

\section{MATERIALS AND METHODS}

\section{Preparation of $A$. lappa aqueous extract}

A. lappa leaves were obtained from the Entre Folhas Group of the Federal University of Viçosa, Minas Gerais, Brazil in July 2001. The plant material was identified and a voucher specimen was deposited in the VIC Herbarium of the Department of Vegetal Biology, Federal University of Viçosa, Minas Gerais, Brazil, bearing the number 28960 . Two aqueous extracts were obtained from the plant material by infusion prepared in the concentrations of 10 and $20 \mathrm{~g}$ of dried leaves/L of water. The aqueous extract submitted to lyophilization yielded 0.21 and $0.42 \%$, respectively.

\section{Animals}

The study was carried out on 100-day-old adult male Wistar rats, weighing between 220 and 275 g. They were obtained from the Department of Health and Nutrition (Federal University of Viçosa, Viçosa, MG, Brazil) and were maintained in individual cages in $12 \mathrm{hL}: 12 \mathrm{hD}$ conditions. They were provided with feed ad libitum for 40 days. These animals were handled and euthanatized in accordance to Ethical Principles for Animal Research established by the Brazilian College for Animal Experimentation (COBEA).

\section{Treatment}

Thirty rats were randomly divided in three groups of ten animals each. All the animals received water and the extract in water bottles attached to the outside of the cage. The control group received only water. Group A and Group B received daily $200 \mathrm{~mL}$ of leaf extract of A. lappa at a dose of 10 and $20 \mathrm{~g} / \mathrm{L}$, respectively (Franco and Santana, 2002). The infusion was prepared daily from dry leaves.

\section{Plasma and biochemical analysis}

The blood samples were collected and centrifuged at $7100 \times \mathrm{G}$ for 15 minutes. The plasma was removed to be assayed for albumin, alanine aminotransferase (ALT), aspartate amiotrasferase (AST), calcium, chlorine, creatinine, direct bilirubin, gamma glutamyl transpeptidase (GGT), phosphorus, total cholesterol, total protein, triacylglycerol, urea and uric acid. All assays were performed using Biolab Diagnostic kits.

\section{Tissue Preparation}

Rats were anesthetized with ether and the thoracic cavity was opened for whole body perfusionfixation with $2.5 \%$ glutaraldehyde in $0.1 \mathrm{M}$ phosphate buffer. The liver was post-fixed with the same fixative for $24 \mathrm{~h}$. Blocks of liver tissue were taken from the median lobe and prepared for embedding in glycol methacrylate (Historesin, Leica) using standard techniques. Subsequently, sections of $4 \mu \mathrm{m}$ thickness were obtained and stained with toluidin blue for microscopic assessment.

\section{Morphometry of liver and histopathological examination}

The histological sections were examined under a light microscope using a 121 intersection grid placed at the ocular lens, coupled to a $100 \mathrm{X}$ objective. The hepatic parenchyma was classified as one of the following: hepatocyte cytoplasm or nucleus, hepatic sinusoids, degenerative hepatocytes, central vein, portal space, fatty deposition and inflammatory infiltrate. One thousand points were counted for each animal.

\section{Statistical analysis}

All data were represented as mean \pm standard mean error (S.E.M.) or as percentages. Statistical evaluation of significant difference between the means was performed with one way analysis of variance (ANOVA), followed by Duncan test $\mathrm{p}<$ 0.05 was regarded as significant.

\section{RESULTS}

A lappa administration at the doses of 10 and 20g/L had no apparent effect on liver tissue and biochemical parameters. There were no significant alterations $(p>0.05)$ in the plasma levels of albumin, ALT, AST, calcium, chlorine, direct bilirubin, GGT, phosphorus, total cholesterol, total protein, triacylglycerol, urea and uric acid between the control and treated groups. The creatinine level increased $11.9 \%(\mathrm{p}<0.05)$ in group $\mathrm{A}$, whereas in group $\mathrm{B}$, no significant difference was observed (Table 1). Degenerative hepatocytes were 
observed and they represent $0.1 \%$ in both, A and B groups, and were not observed in the control group. These data was not statistically significant
(Table 2). High degree of fatty deposition was found in the liver of one animal of group A and one in group $\mathrm{B}$.

Table 1- Biochemical parameters of rats treated with different concentrations of A. lappa aqueous extract (mean \pm SEM).

\begin{tabular}{lccc}
\hline Parameter & Control & Group A & Group B \\
\hline Albumin (g/dL) & $4.24 \pm 0.37$ & $4.02 \pm 0.27$ & $3.95 \pm 0.32$ \\
ALT (UI) & $203.20 \pm 70.98$ & $145.40 \pm 22.41$ & $158.25 \pm 44.84$ \\
AST (UI) & $184.20 \pm 2.76$ & $107.83 \pm 17.15$ & $159.80 \pm 40.20$ \\
Calcium (mg/L) & $8.65 \pm 0.61$ & $10.47 \pm 0.94$ & $11.22 \pm 1.30$ \\
Chlorine(mmol/L) & $163.13 \pm 14.06$ & $159.16 \pm 17.60$ & $151.13 \pm 14.42$ \\
Creatinine (mg/dL) & $0.67 \pm 0.03$ & $0.75 \pm 0.02 *$ & $0.68 \pm 0.02$ \\
Direct bilirubin (mg/dL) & $0.33 \pm 0.07$ & $0.29 \pm 0.05$ & $0.21 \pm 0.05$ \\
GAMMA GT (UI) & $4.00 \pm 0.42$ & $4.25 \pm 00.66$ & $3.63 \pm 0.26$ \\
Phosphorus (mg/L) & $12.96 \pm 2.82$ & $11.98 \pm 1.20$ & $9.38 \pm 0.81$ \\
Total cholesterol (mg/dL) & $86.48 \pm 3.23$ & $81.30 \pm 2.59$ & $82.08 \pm 4.20$ \\
Total proteins (g/L) & $63.99 \pm 0.75$ & $63.15 \pm 1.21$ & $63.61 \pm 1.06$ \\
Triacylglycerol (mg/dL) & $45.39 \pm 5.61$ & $39.99 \pm 1.94$ & $41.53 \pm 3.33$ \\
Urea (mg/dL) & $49.84 \pm 1.39$ & $49.92 \pm 1.32$ & $47.06 \pm 1.19$ \\
Uric acid (mg/dL) & $1.29 \pm 0.13$ & $1.43 \pm 0.16$ & $1.39 \pm 0.16$ \\
\hline
\end{tabular}

${ }^{*} \mathrm{p}<0.05$

Table 2- Proportion (\%) of hepatic constituents of rats treated with different concentrations of A. lappa aqueous extract (mean \pm SEM).

\begin{tabular}{lccc}
\hline Parameters & Control & Group A & Group B \\
\hline Hepatocyte nucleus & 11.9 & 10.2 & 10.7 \\
Hepatocyte cytoplasm & 58.2 & 55.4 & 58.1 \\
Hepatic sinusoids & 18.9 & 20.6 & 21.6 \\
Central vein & 2.8 & 2.6 & 1.8 \\
Portal space & 6.5 & 8.1 & 7.1 \\
Fatty deposition & 1.6 & 2.6 & 0.5 \\
Inflammatory infiltration & 0.1 & 0.4 & 0.1 \\
Degenerative hepatocytes & 0.0 & 0.1 & 0.1 \\
\hline
\end{tabular}



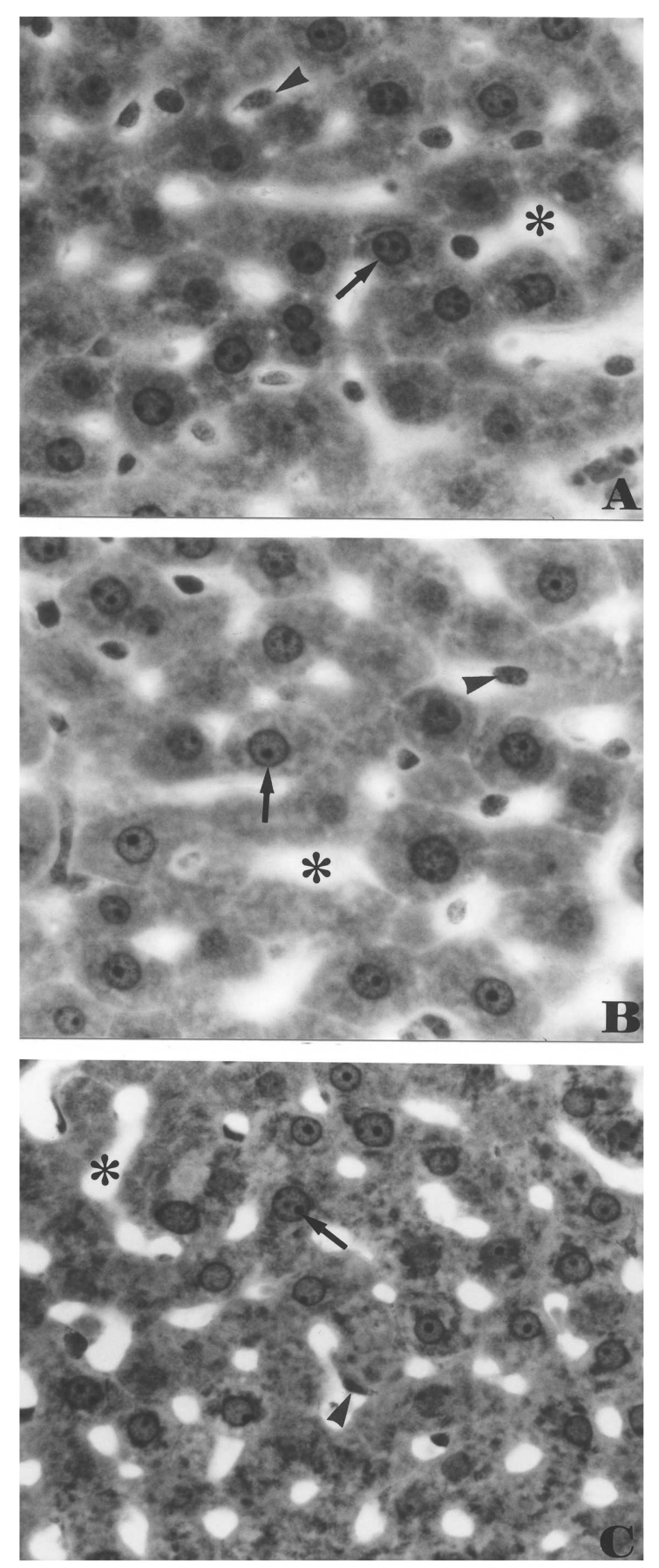

Figure 1- Hepatic tissue of rats treated with different concentrations of A. lappa aqueous extract. A- Group A. B- Group B. C- Control Group. Arrow head: Kupffer cell. Arrow: hepatocytes. Asterisc: Hepatic sinusoids. Toluidin blue/ 1\% sodium borate. X 540.

\section{DISCUSSION}

In recent years, the crude water extract of $A$. lappa, called A. lappa tea, has become a promising and important beverage, because it has ample therapeutic activity (Lin et al., 2002). Therefore, this study was designed to study possible effects of this plant on biochemical parameters and the liver tissue. Plasma levels of transaminases (AST and ALT) and GGT, and liver histopathological and morphometrical changes were used as indicators of hepatotoxicity (Ozcanli, 2006). The increase of the parameters of transaminases and GGT has 
been used as an indicator of damage to liver structural integrity, because these enzymes are cytoplasmatic in location and released into the circulating blood only after structural damage (Janbaz and Gilani, 2000; Hagar, 2004). Moreover, alterations of the other biochemical parameters also are positively correlated with toxicity to the animal (Hagar, 2004). However, this study did not show alteration of the plasma levels of these enzymes and other biochemical parameters, when treated and control groups were compared, with the exception of the creatinine plasma level in group A $(p<0,05)$. This alteration could not be attributed to the treatment, since group A received a lower concentration of extract than group $\mathrm{B}$, in which the plasma level was not altered. The morphological examination of the liver also supported the above results, suggesting that the tea did not damage the hepatocytes. The high degree of fatty deposition found in the liver of one animal of group A and one in group B, was not considered to be a consequence of the treatment, since it occurred in few individuals only. The results supported the concept that hepatoprotective effects could be attributed to $A$. lappa in relation to liver injuries induced by chronic ethanol consumption, or chronic ethanol consumption potentiated by carbon tetrachloride (Lin et al., 2002), tetrachloride and acetaminophen (Lin et al., 2000). However, this study in animals suggested that caution should be taken in using $A$. lappa to treat human patients with kidney stones and gout, since the plasmatic levels of uric acid were somewhat increased in the treated groups. This could occur due to its diuretic property, remembering that some diuretics were known to decrease the rate of uric acid excretion (Iwaki and Yonetani, 1984). Thus, the administration of $A$. lappa extract in the dosage and during the period of time used did not show signs of toxicity, according to the biochemical parameters and the lack of alterations in the liver tissue.

\section{ACKNOWLEDGEMENTS}

The authors would like to acknowledge Dra. Heidi Dolder for correcting the English, and Biofármacos Laboratory for the biochemical parameters analysis. This study was supported by CNPq for aid to Fabrícia de Souza Predes.

\section{RESUMO}

A bardana (Arctium lappa $\mathrm{L}$ ) é uma planta trazida do Japão e aclimatada no Brasil, e é extensamente utilizada na medicina popular em todo mundo. Este estudo foi realizado para avaliar os possíveis efeitos da A. lappa no fígado e nos parâmetros bioquímicos plasmáticos em ratos Wistar adultos. Estes receberam a infusão de bardana nas doses de 10 ou $20 \mathrm{~g}$ de folhas secas /L de água, por 40 dias. Não houve alteração significativa nos níveis plasmáticos de albumina, aspartato transaminase (AST), alanina transaminase (ALT), gamma glutamil transferase (GGT), proteínas totais, colesterol total, uréia, ácido úrico, triglicérides, cálcio, fósforo, bilirrubina direta e cloro. A análise morfológica não revelou alterações histopatológicas no fígado. Os dados bioquímicos e morfológicos não indicaram a toxicidade da bardana.

\section{REFERENCES}

Capasso, R.; Izzo, A.A., Pinto; L., Bifulco, T.; Vitobello, C. and Mascolo, N. (2000), Phytotherapy and quality of herbal medicines. Fitoterapia 71, 5865.

Chen, F.; Wu, A. and Chen, C. (2004), The influence of different treatments on the free radical scavenging activity of burdock and variations of its active components. Food Chemistry, 86, 479-484.

Franco, I.F. and Fontana, V.L. (2002), Ervas and Plantas. A medicina dos simples. Livraria Vida, Erexim, pp. 208.

Hagar, H H. (2004), The protective effect of taurine against cyclosporine $\mathrm{A}$ - induced oxidative stress and hepatotoxicity in rats. Toxicology Letter, 151, 335343.

Iwaki, k. and Yonetani, Y. (1984), Decreased renal excretion of uric acid following diuretic administration in rats. Japan Journal of Pharmacology, 34, 389-396.

Janbaz, K.H. and Gilani, A.H. (2000), Studies on preventive and curative effects of beberine on chemical- induced hepatotoxicity in rodents. Fitoterapia, 71, 25-33.

Leonard, S.S.; Keil, D.; Mehlman, T,; Proper, S.; Shi, X. and Harris, G.K. (2006), Essiac tea: Scavenging of reactive oxygen species and effects on DNA damage. Journal of Ethnopharmacology, 103, 288-296. 
Lin, C.C.; Lu, J.M.; Yang, J.J.; Chuang, S.C. and Ujiie, T. (1996), Anti-inflammatory and radical scavenge effects of Arctium lappa. American Journal of Chinese Medicine, 24, 127-137.

Lin, S.C.; Chung, T.C.; Lin, C.C.; Ueng, T.H.; Lin, Y.H.; Lin, S.Y. and Wang, L.Y. (2000), Hepatoprotective effects of Arctium lappa on carbon tetrachloride- and acetaminophen- induced liver damage. American Journal of Chinese Medicine, 28, 163-173.

Lin, S.C.; Lin, C.H.; Lin, C.C.; Lin, Y.H.; Chen, C.F.; Chen, I.C. and Wang, L.Y. (2002), Hepatoprotective effects of Arctium lappa Linne on liver injuries induced by chronic ethanol consumption and potentiated by carbon tetrachloride. Journal of Biomedical Science, 9, 401-409.

Ozcanli, T.; Erdoganb, A.; Ozdemirc, S.; Onenc, B.; Ozmenc, M.; Doksatc, K. and Sonsuzd A. (2006),
Severe liver enzyme elevations after three years of olanzapine treatment: a case report and review of olanzapine associated hepatotoxicity. Prog Neuropsychopharmacol Biol Psychiatry, 30, 11631166.

Pereira, J.V.; Bergamo, D.C.B.; Pereira, J.O.; França, S.C.; Pietro, R.C.L.R. and Silva-Souza, Y.T.C. (2005), Antimicrobial activity of Arctium lappa constituents against microorganisms commonly found in endodontic infection. Brazilian Dental Journal, 16, 192-196. 